\title{
Carbon farming in hot, dry coastal areas: an option for climate change mitigation
}

\author{
K. Becker ${ }^{1}$, V. Wulfmeyer ${ }^{2}$, T. Berger ${ }^{3}$, J. Gebel ${ }^{4}$, and W. Münch \\ ${ }^{1}$ Institute for Animal Production in the Tropics and Subtropics, University of Hohenheim, 70593 Stuttgart, Germany \\ ${ }^{2}$ Institute of Physics and Meteorology, University of Hohenheim, 70593 Stuttgart, Germany \\ ${ }^{3}$ Institute for Agricultural Economics and Social Sciences in the Tropics and Subtropics, University of Hohenheim, \\ 70593 Stuttgart, Germany \\ ${ }^{4}$ S.T.E.P. Consulting GmbH, 52066 Aachen, Germany \\ ${ }^{5}$ EnBW Energie Baden-Württemberg A.G., 76131 Karlsruhe, Germany
}

Correspondence to: V. Wulfmeyer (volker.wulfmeyer@uni-hohenheim.de)

Received: 23 September 2012 - Published in Earth Syst. Dynam. Discuss.: 10 October 2012

Revised: 18 June 2013 - Accepted: 19 June 2013 - Published: 31 July 2013

\begin{abstract}
We present a comprehensive, interdisciplinary project which demonstrates that large-scale plantations of Jatropha curcas - if established in hot, dry coastal areas around the world - could capture 17-25t of carbon dioxide per hectare per year from the atmosphere (over a $20 \mathrm{yr}$ period). Based on recent farming results it is confirmed that the Jatropha curcas plant is well adapted to harsh environments and is capable of growing alone or in combination with other tree and shrub species with minimal irrigation in hot deserts where rain occurs only sporadically. Our investigations indicate that there is sufficient unused and marginal land for the widespread cultivation of Jatropha curcas to have a significant impact on atmospheric $\mathrm{CO}_{2}$ levels at least for several decades.

In a system in which desalinated seawater is used for irrigation and for delivery of mineral nutrients, the sequestration costs were estimated to range from 42-63 EUR per tonne $\mathrm{CO}_{2}$. This result makes carbon farming a technology that is competitive with carbon capture and storage (CCS). In addition, high-resolution simulations using an advanced land-surface-atmosphere model indicate that a $10000 \mathrm{~km}^{2}$ plantation could produce a reduction in mean surface temperature and an onset or increase in rain and dew fall at a regional level. In such areas, plant growth and $\mathrm{CO}_{2}$ storage could continue until permanent woodland or forest had been established. In other areas, salinization of the soil may limit plant growth to 2-3 decades whereupon irrigation could be ceased and the captured carbon stored as woody biomass.
\end{abstract}

\section{Introduction}

It is now widely accepted that anthropogenic greenhouse gas emissions are causing an increase in global mean temperature and an acceleration of the global water cycle (IPCC, 2007). Unfortunately, in spite of the great threat posed by climate change to the earth's environment and humankind, global agreements on greenhouse gas reduction have so far been largely ineffective. During the last decade, the emission rate of $\mathrm{CO}_{2}$ compared with the period 1990-2000 has even accelerated (Le Quéré et al., 2009). Consequently, a variety of geoengineering approaches have been suggested for mitigating climate change. These options may be separated into purely technological approaches such as sun shading, increase of surface albedo by whitening of buildings, and carbon capture and storage (CCS) (Boyd, 2008) or biogeoengineering options (see, e.g., Betts, 2007). A comparison of the effectiveness of different proposals can be found in Lenton and Vaughan (2009). However, this analysis disregards feedbacks in the water cycle.

Recently, technological approaches such as CCS have become of great interest, as this technology may permit the reduction of $\mathrm{CO}_{2}$ emission rates by power plants (IPCC, 2005). However, CCS has also been strongly questioned because of the large amounts of energy needed for its implementation, which reduces the efficiency of power plants, and the huge financial investments that this technology requires. As a matter of fact, CCS has only the potential to reduce emissions 
from power plants but not from other sources. Furthermore, it is not yet clear whether the long-term storage of carbon can really be guaranteed without leakage into the environment.

Therefore, it is reasonable to explore bio-geoengineering approaches designed to change land-surface properties using the natural properties of vegetation. These include either modifications of energy partitioning by different types of vegetation or afforestation measures leading to a reduction in the levels of atmospheric $\mathrm{CO}_{2}$ and land-surface temperature. Both are options extensively investigated within IPCC (Metz et al., 2007). For instance, Ridgwell et al. (2009) and Doughty et al. (2010) studied the impact of an increase of agricultural crop albedo using global climate models. In midlatitudes, a consistent reduction of regional temperature of about 0.25 degrees per 0.01 increase in albedo was predicted. Different relationships between these two parameters occur in other regions such as the tropics. However, global climate models are limited with respect to the correct quantitative simulation of land-surface atmosphere feedback and also to the response of the water cycle including precipitation (e.g., Hohenegger et al., 2009). These aspects call for further studies using high-resolution climate models that avoid the parameterization of convection and that improve the interaction between land-surface heterogeneities and orography with the atmosphere.

One interesting option is afforestation which has several effects, simultaneously. First, carbon sequestration in biomass both above and below ground is a possible mitigation strategy (Metz et al., 2007). In the following discussion, we refer to this bio-geoengineering option as Carbon Farming. Secondly, daily surface temperatures may be reduced in subtropical regions due to changes in the surface energy balance. This depends critically on the partitioning of the energy balance into sensible and latent heat fluxes and its feedback to the atmospheric boundary layer (ABL), clouds, and precipitation. Thirdly, a variety of additional effects may be achieved such as the production of bio fuel and nutrients as well as the creation of a healthier environment. However, carbon farming must not compete with food production so afforestation measures should concentrate on land areas such as desert regions that are not likely to be used for conventional farming and which are not oversalted by previous unsustainable agricultural practises.

Recently, Ornstein et al. (2009) investigated this idea in desert regions on a global scale. Using a global climate model, they simulated large-scale reductions of surface temperature in the Sahara and the Australian desert. They also studied large-scale feedback processes such as teleconnection. Focusing on Eucalyptus sp. plantations, they stated that a significant mitigation of global carbon emission may be achieved if the Saharan or Australian deserts are cultivated. Furthermore, they found that their models predicted a large increase in precipitation in desert regions and related this to the Charney effect (Charney, 1975). With respect to irrigation, Ornstein et al. (2009) stated that the extremely valuable aquifers, which are available in some desert regions, should not be further exploited but considered instead the application of recent advances in desalination technology such as reverse osmosis. They discussed the costs and technological requirements to realize such a large-scale, international project covering areas of the order of $10^{9}$ ha.

These results are encouraging and the interest in afforestation for production of biodiesel and application of the Clean Development Mechanism (CDM) is steadily increasing (see, e.g., cdm.unfccc.int, Kumar et al., 2011). However, several caveats remain with respect to technological and scientific aspects: the technologies for realising huge afforestation efforts such as irrigation with desalination plants are still in their infancy. It is not clear whether the carbon sequestering potential of suitable plants such as Eucalyptus sp. and Jatropha curcas can be maintained over large plantation areas, but ultimately the only way to find out will be to try.

Furthermore, it is well known that coarse-scale global climate models have severe deficiencies when it comes to simulating land-surface-cloud-precipitation feedback. For instance, Hohenegger et al. (2009) demonstrated that coarsescale models, which require a convection parameterization, and convection-permitting models (grid resolution $<4 \mathrm{~km}$ ) even give feedbacks between soil moisture and precipitation of different sign. This is a critical issue for the credibility of climate simulations. These results have been refined by Rotach et al. $(2009 a, b)$ and Wulfmeyer et al. $(2008,2011)$ who demonstrated severe deficiencies in models with convection parameterization when they are applied to mountainous regions or areas with strong land-surface heterogeneity. This is also the case in coastal desert regions. Therefore, it is highly questionable whether resilient quantitative results concerning land-surface feedback and precipitation can be achieved with models that use convection parameterization.

Consequently, we are convinced that an analysis of afforestation measures should be based on a thorough transdisciplinary scientific study on a local scale combining an analysis of the costs, the carbon binding potential, and the economic efficiency of these plantations in connection with the CDM. Here, the technological challenges can be studied in more detail and may be complemented and verified by results from plantations. Furthermore, land-surfaceatmosphere feedback processes can be studied more realistically using high-resolution models. This combination of modeling efforts is also essential for studying the sustainability of carbon farming.

This work is intended to extend previous work in this area and to close an important gap in the analysis of afforestation projects in dry coastal areas. We focus on Jatropha curcas because we consider this plant to be one of the more promising and robust plants suitable for desert regions. Also, the authors of this paper have much specialized knowledge of and relevant data for this plant, its potentialities and requirements. That said, we are also well aware that other tree crops, especially Eucalyptus sp. or mixtures of various species, may be 
more suitable in many cases. Mixed crops can include food and fodder crops and also have the advantage that they produce more diverse ecosystems and thus reduce the danger of epidemics and large scale attack by pests. However the methodology and analysis that we apply here to Jatropha curcas could, with suitable raw data, be adapted to these other species and mixtures. With this approach and the application of available data, we are aiming at an analysis of the performance of the plantation over a time period of 1-3 decades. This may also provide an appropriate basis for the assessment of the fate of large-scale plantations for up to a century in future research.

This paper is organized as follows: in Sect. 2 we introduce the project strategy and explain the goals and the interactions of the project partners. In Sect. 3, the results of the study are presented. The biomass production and carbon sequestration potential of Jatropha curcas plantations is presented in Sect. 3.1; the irrigation, desalination, and energy supply costs in Sect. 3.2; and the impact on the regional climate in Sect. 3.3. An overview of other expected impacts is presented in Sect. 4 followed by some conclusions in Sect. 5 .

\section{Project strategy}

An extensive, transdisciplinary study was performed to explore the interwoven local technological, economical, and climatological impacts of carbon farming. In particular, the economic potential of this approach with respect to the CDM was studied. First of all, an important condition was laid down namely that carbon farming must not compete with food production, as cropland is becoming increasingly scarce. According to Costanza et al. (1997), only 1.4 billion ha of the approximately 15 billion ha of earth's land area is currently usable for crops. Extrapolating recent trends in population growth and land degradation, this would leave no more than $1100 \mathrm{~m}^{2}$ to nourish each of the 9 billion inhabitants expected by 2050. At present, 1.9 billion ha of former crop land are degraded and unusable or barren. There are also an additional 1 billion ha of desert land in dry coastal areas with minimum night-time temperatures that seldom, if ever, fall below $12{ }^{\circ} \mathrm{C}$. Both types of land are potential areas for carbon farming. The dry coastal areas have been degraded over a long period of time due to lack of precipitation or natural water sources. The very low precipitation amounts are caused by large-scale suppression of convection, e.g., by Hadley cell subsidence, or local suppression of convection either by upwelling of cold air by ocean currents or by atmospheric divergence caused by increasing land friction. Therefore, in these "natural deserts" land degradation caused by poor agricultural practices such as inadequate irrigation leading to high salinity of the soil is hardly an issue. However, strategies for minimizing contamination of the soil must certainly be taken into account and are discussed in Sects. 3.2 and 4.
Decisions regarding the economic and ecological value of carbon farming are possible only if they are based on a comprehensive assessment of the potential benefits and costs. Before large-scale projects can be established in hot dry coastal areas, in-depth plans for their implementation will need to be drawn up.

Figure 1 depicts the carbon farming concept and shows the key processes involved. Our new evaluation of carbon farming takes the following key factors into account:

- the growth of robust plants under extreme weather conditions,

- technical advances in seawater desalination, and

- an understanding of the impact of greening deserts on weather and climate.

Power and desalination plants are located at the coast line of a dry desert. The output of the desalination plant is used for irrigation of the plantations. The operation of the power plant can be supported by burning part of the biomass produced. If the plantation is large enough, onset of dew and rainfall is expected due to the modification of processes associated with the atmospheric boundary layer (ABL). In Fig. 1, the ABL top is indicated by the blue hyper surface. The extra precipitation would reduce the amount of water needed for irrigation and create a more moderate local climate.

Our analysis of the environmental impacts was made using a hierarchy of computer models supported by extensive research on the input parameters. We applied the derived climate models to two proposed pilot sites in Oman and Mexico using results from a plantation of Jatropha curcas in Egypt. We used primary and secondary data for technical analyses, and created simulations of irrigation requirements and regional land-vegetation-atmosphere feedbacks. The study is complemented by a description of some non-technical constraints and suggestions as to how such a project may be set up and implemented.

\section{Results}

\subsection{Biomass production and carbon sequestration}

Many extended coastal desert areas could be cultivated with robust perennial plants, using desalinated sea water. These include trees such as Acacia saligna, Azadirachta indica, Eucalyptus camaldulensis, Eucalyptus microtheca, Moringa oleifera, Pongamia pinnata and Jatropha curcas, shrubs such as Prosopis cineraria, Ricinus communis, and Simmondsia chinensis, and reeds and grasses such as Arundo donax L, LIHD-prairie grasses and Miscanthus $x$ giganteus. The trees in this list have been reported to produce an above ground biomass of between 5-25 $t$ dry mass per ha per year equivalent to 2.4-12t of carbon per ha per year (Steen and Reed, 2004) and the perennial grasses up to $51 \mathrm{t}$ above ground 


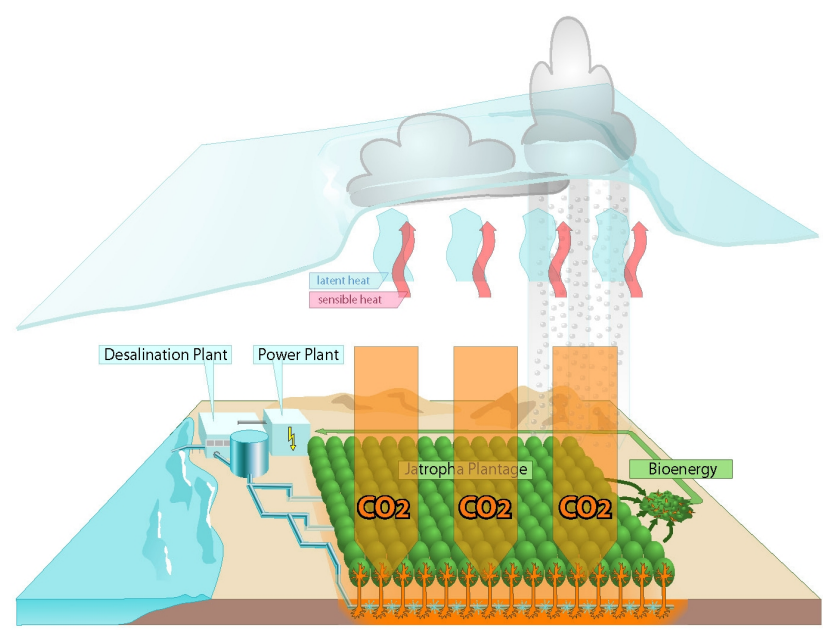

Fig. 1. Outline of the carbon farming project. The top of the atmospheric boundary layer is indicated by the blue hyper surface.

biomass per ha per year (Angelini Luciana et al., 2009). Suitably deployed, these plants could transform unused, barren lands into long-term carbon sinks (Fairless, 2007). The carbon efficiency of this bio-ecosystem would compare favourably with all other existing processes for carbon storage and sequestration, including the cultivation of bio fuels (Righelato and Spracklen, 2007).

Jatropha curcas is a member of the family Euphorbiaceae, genus Jatropha. The plant is very well adapted to harsh tropical and sub-tropical environments and is capable of growing in hot, hyper arid deserts (Fairless, 2007) but, like most plants, optimum growth requires regular, if minimal, irrigation. Unlike many annual crops that have been the subject of centuries of domestication, Jatropha curcas is a wild, perennial plant that has received little scientific attention to date. For this reason, performance parameters vary considerably among different provenances, a fact which is of great significance for future domestication programs (Popluechai et al., 2009).

Long-term ( $>3 \mathrm{yr}$ ) empirical data on the growth of Jatropha curcas from dry coastal areas are not yet available. We therefore estimated biomass production and carbon sequestration from measurements taken on a 100 ha Jatropha curcas plantation in Luxor, Egypt, containing 940 plants ha $^{-1}$. The rapid growth of these plants is demonstrated in Fig. 2. The plants in this location are still slightly less than 4 yr old, and the site is comparable to a hot, dry coastal area because day temperatures exceed $40^{\circ} \mathrm{C}$ for 260 days of the year and precipitation is very sporadic with a long-term average of only $0.3 \mathrm{~mm}$ per year. Sewage water from the city of Luxor was used for irrigation - not desalinated sea water. The use of such waste water would also be a possibility in some hot, dry coastal areas, but cities of any size are comparatively rare in these places and the amount of water available would not be nearly enough to support the scale of plantations envisaged.
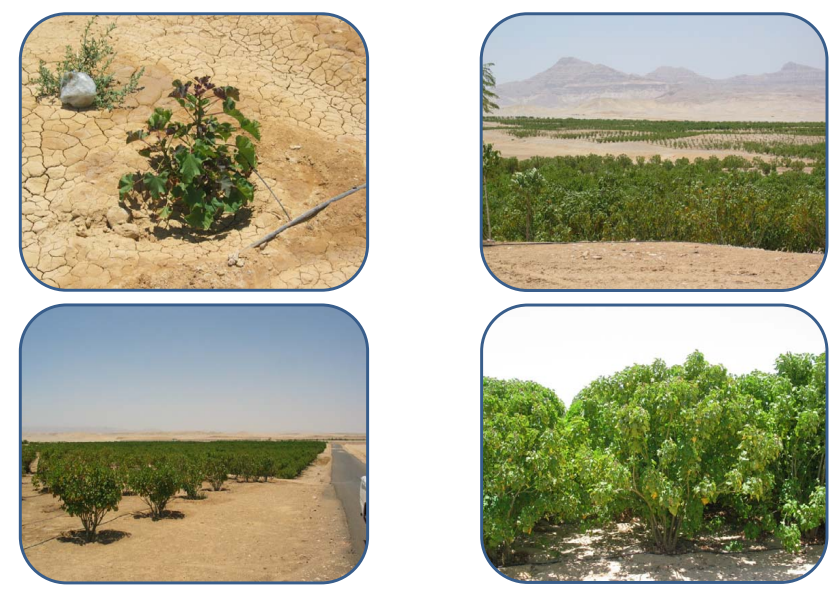

Fig. 2. Scenes from the Jatropha curcas plantation at Luxor, Egypt.

The extensive use of sewage water would also not be recommended in very dry areas because of salinization. In the literature, mixed results are found with respect to the sensitivity of Jatropha to salinity. Whereas Tal et al. (1979) found a very low sensitivity of plant growth on salinity and Silva et al. (2010) found adaptive physiological processes reducing salinization-induced stresses; in contrast, Rajaona et al. (2012) observed that salt stress influenced Jatropha's canopy development and the $\mathrm{CO}_{2}$ assimilation rate. Without extensive flushing, it is unlikely that more than one crop of Jatropha curcas could be grown before the build-up of salt in the soil prevented further growth, in which case carbon sequestration could be done only once. However, long-term experience is lacking and there is a need for more experiments and analyses on large-scale plantations.

One issue may be environmental safety, as concerns have been raised in the literature about the invasiveness of the Jatropha species. But this is actually only a problem with Jatropha gossypiitolia (Achten, 2007). Based on our observations in Luxor, Egypt, we do not expect major problems in this respect, as the proliferation of Jatropha curcas is confined to the area under irrigation by the neighboring hot desert areas. Growing Jatropha curcas in large-scale monoculture may also involve risks related to plant health. Jatropha curcas is largely immune to diseases and pests but insect infestations such as flea beetle (Aphtona species) (Holl et al., 2007), whitefly (B.tabaci), the leaf and capsule borer (Pampelia morosalis) and bugs such as Scutellera nobilis and Chrysocoris purpureus have been reported in a few cases. It is also susceptible to a number of viral diseases, e.g., the Jatropha Mosaic Virus (e.g., http://www.nri.org/component/content/article/69-projectwebsites/480-technology-development-for-managing-thepests-and-diseases-of-a-bio-diesel-crop-jatropha-curcas-1). Since only limited empirical data exist concerning the toxicity of Jatropha curcas fruits consumed by humans - with the exception of the two edible, non-toxic genotypes, Jatropha 
curcas (Makkar et al., 1998) and Jatropha platyphylla (Makkar et al., 2010) - Achten et al. (2007) recommend precautionary measures. The main toxic components of Jatropha curcas are the phorbol esters. These are found in all plant parts and act as a protection mechanism against browsing by animals.

From the plantation in Luxor, fifty, 32 month old Jatropha curcas bushes were chosen at random from among 94 000. Trunk circumference at ground level and height of each bush were measured to $\pm 1 \mathrm{~cm}$, and the bushes were dug up. Care was taken to include as many of the roots as possible, but very fine root systems were discarded. The bushes were separated into their main morphological components (roots, trunk, and branches). The roots were washed to remove sand and dried and then all components were weighed to $\pm 0.1 \mathrm{~kg}$. After chopping and homogenising the three fractions, samples were taken, placed in sealed plastic bags and sent to Germany where dry mass was determined by heating to constant weight at $105^{\circ} \mathrm{C}$ over 3-4 days. Carbon content was calculated as $50 \%$ of dry mass (see Table 1).

The problem of obtaining longer-term biomass data for Jatropha curcas has already been mentioned. To get reasonable estimates, we used data on the diameter of Jatropha curcas trees quoted by Holl et al. (2007) from trees up to $12 \mathrm{yr}$ old and fitted a growth curve to a graph of age versus diameter at ground level (DGL). According to forestry experts, an assumed average rate of growth of DGL of $4 \mathrm{~mm}$ per year from age 12 on could then yield a $20 \mathrm{yr}$ value for DGL of $412 \mathrm{~mm}$. We then used an allometric equation of Sampaio and Silva (2005) for Jatropha mollissima in Brazil to calculate the most likely biomass at $20 \mathrm{yr}$. This equation predicted that the average dry biomass would be $140 \mathrm{~kg}$ per tree above ground and $55 \mathrm{~kg}$ below ground.

Recently, Hellings et al. (2012) published allometric equations based on their destructive analysis of Jatropha trees in Northern Tanzania. These authors experienced similar problems to us in that most of their sample trees were 2.5$4.0 \mathrm{yr}$ old with just one 7 and one $25 \mathrm{yr}$ specimen. However, their results are similar in some respects to ours. For example, their $25 \mathrm{yr}$ old tree had a DGL of $433 \mathrm{~mm}$, whereas our predicted value for a $20 \mathrm{yr}$ old tree was $412 \mathrm{~mm}$. When we applied their allometric equations to a $412 \mathrm{~mm}$ diameter tree, we obtained values of 165 and $146 \mathrm{~kg}$ for total and above ground woody dry biomass respectively. The relevant equations were: $\mathrm{TWD}=0.0042 \mathrm{DGL}^{2.8361}$ and AGWD $=0.0019$ DGL $^{3.0248}$ where TWD is Total Woody Dry matter and AGWD is Above Ground Woody Dry matter.

There was good agreement for the prediction of AGWD but the below ground woody biomass (TWD-AGWD) was substantially lower using these equations (19 versus $55 \mathrm{~kg}$ or $13 \%$ versus $28 \%$ of TWD). The value of $13 \%$ was lower than the value calculated directly from the data in Helling et al. (2012) $(28.1 \% \pm 6.5 \%$ which includes the $25 \mathrm{yr}$ old tree that gave a value of $30.6 \%$ ), or the data of Firdaus et al. (2010) quoted by Hellings et al., 2012) which gave values of $24-51 \%$, or that of the data in Table 2 of this paper (average $24.3 \%$ ).

In view of the above we have used our original estimates in subsequent calculations in this paper viz. a value of $140 \mathrm{~kg}$ for the AGWD of a $20 \mathrm{yr}$ old tree, which is slightly lower than the value derived from the data of Hellings et al. (2012), and a value of $195 \mathrm{~kg}$ for the TWD of a $20 \mathrm{yr}$ old tree, which seems consistent with the ratios of AGWD to TWD reported here and elsewhere. We stress that these values are tentative and based on sparse data but subsequent calculations are sufficiently transparent that they can easily be repeated if or when more robust data become available.

At a planting density of 940 trees per hectare a TWD of $195 \mathrm{~kg}$ would give a total dry biomass production of $183.3 \mathrm{t}$ over $20 \mathrm{yr}$. Without including the leaves and fruits which, in a hot desert climate accumulate as litter under the trees, this would translate into a total of $91.7 \mathrm{tha}^{-1}$ of carbon. If we include the fruits and the leaf litter, then the figure for carbon sequestration by a Jatropha curcas plantation could be up to $50 \%$ higher reaching about $137.6 \mathrm{tha}^{-1}$ of carbon by year 20 . Note that this estimate does not include possible carbon sequestration in the soil and the yearly average range of 4.9$6.9 \mathrm{tha}^{-1} \mathrm{yr}^{-1}$ is well within the range of $2.4-12 \mathrm{tha}^{-1} \mathrm{yr}^{-1}$ reported above for a variety of perennial desert trees.

In terms of $\mathrm{CO}_{2}$ sequestration, a range of 4.9$6.9 \mathrm{tha}^{-1} \mathrm{yr}^{-1}$ of carbon translates into an average of $21.6 \mathrm{tha}^{-1} \mathrm{yr}^{-1}$ of $\mathrm{CO}_{2}$ or $2.16 \mathrm{~kg} \mathrm{~m}^{-2} \mathrm{yr}^{-1}$. We have used this value to estimate the amount of anthropogenic $\mathrm{CO}_{2}$ that could be removed by the establishment of large-scale Jatropha curcas plantations.

Given the total mass of the atmosphere $m_{\mathrm{atm}} \approx 5.13 \times 10^{18} \mathrm{~kg}$, the molecular weight of dry air $M_{\mathrm{D}}=28.96 \mathrm{~g} \mathrm{~mol}^{-1}$, and the molecular weight of $\mathrm{CO}_{2}$ $M_{\mathrm{CO}_{2}}=44.01 \mathrm{~g} \mathrm{~mol}^{-1}$ then the relationship between the mass of $\mathrm{CO}_{2}$ in the atmosphere $\left(m \mathrm{CO}_{2}\right)$ and the volume mixing ratio of $\mathrm{CO}_{2}$ in dry air $\left(V_{\mathrm{CO}_{2}}\right)$ is

$m_{\mathrm{CO}_{2}} \cong m_{\mathrm{atm}} \frac{M_{\mathrm{CO}_{2}}}{M_{\mathrm{D}}} V_{\mathrm{CO}_{2}} \cong V_{\mathrm{CO}_{2}} 7.8 \times 10^{18} \mathrm{~kg}$.

Table 2 gives values of $V_{\mathrm{CO}_{2}}, m_{\mathrm{CO}_{2}}$, and the corresponding mass of carbon, $m_{\mathrm{C}}\left(m_{\mathrm{C}}=m_{\mathrm{CO}_{2}} / 3.67\right)$ today and prior to the industrial revolution. From these values we can see that the increase in $V_{\mathrm{CO}_{2}}$ over this period was around $105 \mathrm{ppm}$, which is equivalent to $819 \mathrm{Gt}$ of $\mathrm{CO}_{2}$.

Using Eq. (1) and the average value for the amount of $\mathrm{CO}_{2}$ likely to be sequestered by planting Jatropha curcas $\left(2.16 \mathrm{~kg} \mathrm{~m}^{-2} \mathrm{yr}^{-1}\right)$, simple calculations allow several interesting and important conclusions to be drawn.

a. Since the present rate of increase of $V_{\mathrm{CO}_{2}}$ is around $2 \mathrm{ppm}$ per year, stabilising $V_{\mathrm{CO}_{2}}$ at its present level would require the planting of $0.73 \times 10^{9}$ ha of Jatropha curcas which is just under three quarters of the $10^{9}$ ha of desert and marginal land we estimate to be suitable for Jatropha curcas cultivation. 
Table 1. Dry matter content and calculated carbon content of the twigs, stems and roots of 32 months old Jatropha curcas trees from a plantation in the desert of Luxor, Upper Egypt.

\begin{tabular}{lllllll}
\hline & & \multicolumn{5}{c}{ Kg dry matter per tree } \\
\cline { 3 - 7 } $\begin{array}{l}\text { Number } \\
\text { of trees }\end{array}$ & $\begin{array}{l}\text { Plant } \\
\text { height }(\mathrm{m})\end{array}$ & Twigs & Stem & Root & $\begin{array}{l}\text { Total dry } \\
\text { matter }\end{array}$ & $\begin{array}{l}\text { Total } \\
\text { carbon }\end{array}$ \\
\hline 50 & $3.25 \pm 0.6$ & $4.5 \pm 2.3$ & $12.4 \pm 4.3$ & $4.1 \pm 1.6$ & 21.0 & 10.5 \\
\hline
\end{tabular}

Table 2. The volume mixing ratio of $\mathrm{CO}_{2}$ in the atmosphere $\left(V_{\mathrm{CO}_{2}}\right)$, the mass of $\mathrm{CO}_{2}\left(m_{\mathrm{CO}_{2}}\right)$ and the derived mass of carbon $\left(m_{\mathrm{c}}\right)$.

\begin{tabular}{llll}
\hline & $V_{\mathrm{CO}_{2}}, \mathrm{ppm}$ & $m_{\mathrm{CO}_{2}, \mathrm{Gt}}$ & $m_{\mathrm{c}}, \mathrm{Gt}$ \\
\hline Preindustrial & 280 & 2182.9 & 596.4 \\
Present day & 385 & 3001.4 & 820.1 \\
Annual increase & $1.0-2.0$ & $7.8-15.6$ & $2.2-4.4$ \\
\hline
\end{tabular}

b. If the remaining $0.28 \times 10^{9}$ ha were also planted, this area would, over a $20 \mathrm{yr}$ period, reduce $V_{\mathrm{CO}_{2}}$ by $17.5 \mathrm{ppm}$ or $16.6 \%$ of the total increase in $\mathrm{CO}_{2}$ since the industrial revolution.

c. Around $2400 \mathrm{~km}^{2}$ of Jatropha curcas would be required to remove the $5 \mathrm{Mt}$ of $\mathrm{CO}_{2}$ produced annually by a typical, modern, coal fired power station $(1000 \mathrm{MW}$, 5000 full load hours, $45 \%$ net electrical efficiency) and $69400 \mathrm{~km}^{2}$ would absorb all the $\mathrm{CO}_{2}$ produced by motor vehicles in Germany (about 150 Mt per year).

The predicted reduction levels in $\mathrm{CO}_{2}$ can be achieved as long as the plants are growing at the expected rate for 1-3 decades. Therefore, carbon farming has the potential to influence the atmospheric $\mathrm{CO}_{2}$ level at least over this time period. The fate of large-scale plantations beyond this time period needs more research and experiments. Some options are discussed in Sect. 4.

\subsection{Irrigation, desalination, energy supply and associated costs}

The plants in Luxor were irrigated with an open-line subsurface irrigation system that delivered $20 \mathrm{~L}$ of water per plant every 7 days during the hot season (240 days) and every 10 days during the cold season (125 days) which was enough for optimum plant growth. This translates into roughly $880 \mathrm{~m}^{3} \mathrm{ha}^{-1} \mathrm{yr}^{-1}$ for 940 plants ha ${ }^{-1}$, which corresponds to $<100 \mathrm{~mm} \mathrm{yr}^{-1}$. The root system of the plants that were harvested at 32 months typically covered an area of less than $1 \mathrm{~m}^{2}$ so this type and level of irrigation was equivalent to $880 \mathrm{~mm} \mathrm{yr}^{-1}$ over this area.

This level of irrigation is rather more than that recommended for Jatropha curcas by Gebel and Yüce (2008) who suggest using $17500 \mathrm{~m}^{3} \mathrm{~d}^{-1}$ for a 10000 ha plantation which works out at $639 \mathrm{~m}^{3} \mathrm{ha}^{-1} \mathrm{yr}^{-1}$. Application of the FAO CropWat model using data from Holl et al. (2007) also gave similar results. This simulation takes into account local temperatures and rainfall. It gave results that were $10 \%$ higher than our Luxor data for a proposed site in Oman and $50 \%$ less for a proposed site in Mexico where annual rainfall was appreciably higher than that in either Oman or Luxor.

The harvested trees had no discernible tap roots, and the soil outside the area watered by the irrigation system was dry indicating that no other source of water such as ground water was available to the plants.

Sewage water as used in the Luxor project will also provide the plants with nutrients. According to the analyses quoted by Hussein et al. (2004) the treated effluent contains $22.0,3.8$ and $22.4 \mathrm{ppm}$ of N, P and K, respectively. The quantity of water applied to the plants (ca. $900 \mathrm{~m}^{3} \mathrm{ha}^{-1} \mathrm{yr}^{-1}$ ) would provide $19.8,3.4$ and $20.2 \mathrm{~g}$ of $\mathrm{N}, \mathrm{P}$, and $\mathrm{K}$, respectively to each plant per year. These amounts plus the nutrients available from the soil were enough to promote healthy plant growth. In our proposed system using desalinated water, these and other essential minerals would have to be provided dissolved in the irrigation water.

Over recent decades, seawater desalination has become technically and economically feasible. The two main techniques currently used in large scale plants are illustrated in Fig. 3. The essential difference between the two desalination methods is the form of energy needed for the separation of water from salt. While thermal desalination (TD) processes need both heat to evaporate the water and electricity to pump it, reverse osmosis (RO) only uses electricity for the high pressure pumps that overcome the osmotic pressure of seawater. Based on the experiences gained in Luxor we could assume that, after an initial growth phase of about three years, biomass would begin to accumulate in the form of trimmings, withered leaves and nuts. This biomass can be used as an energy source. According to Gebel and Yüce (2008), 5 metric tons of dry biomass with a heat of combustion of $18.5 \mathrm{MJ} \mathrm{kg}^{-1}$ become available per hectare per year in the form of nuts, leaves, and trimmings. This material from a 10000 ha plantation could therefore be burnt to produce a continuous heat output of $30000 \mathrm{~kW}$. This material has not been included in the estimation of carbon sequestration and would provide enough energy to produce steam either as the first stage in a thermal desalination plant or to drive a turbine to generate electricity for a RO plant. 

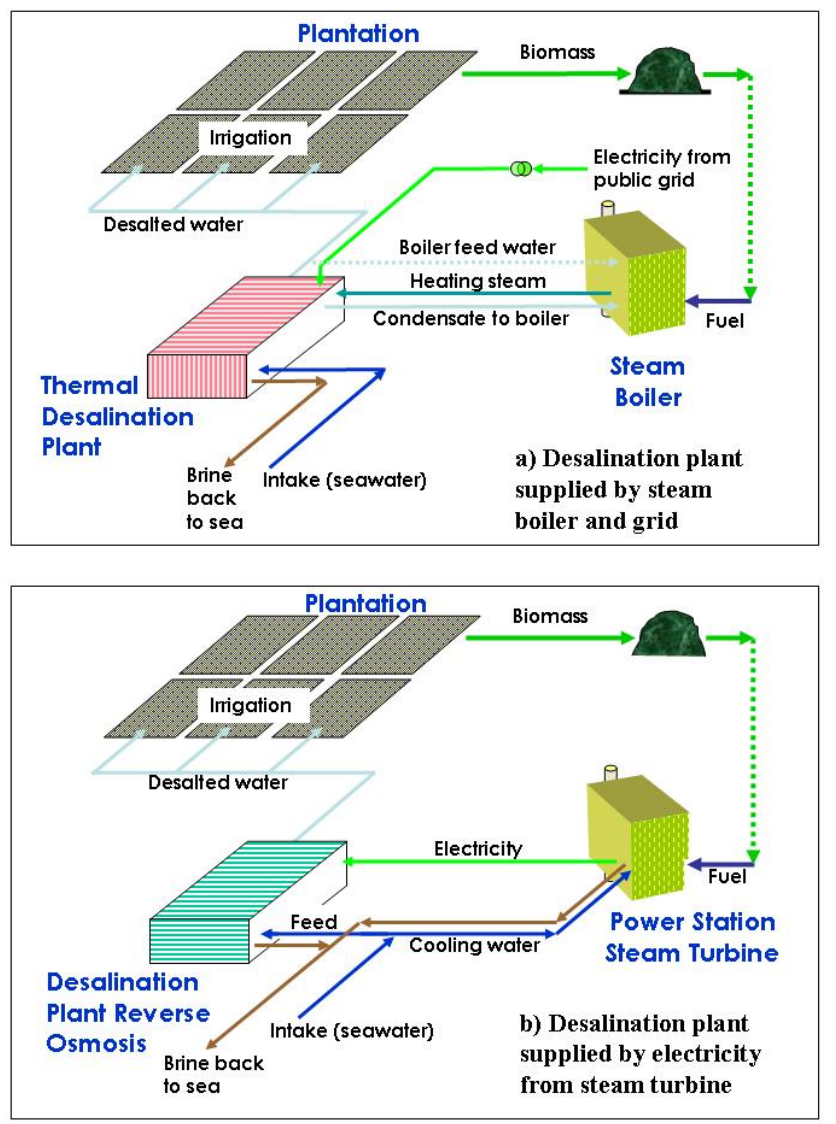

Fig. 3. Two methods for removing salt from seawater.

Several thousand desalination plants of various capacities presently operate worldwide producing more than 50 million $\mathrm{m}^{3}$ of desalinated water per day. The largest plants are usually coupled directly to a power station for their energy supply and deliver around $50000 \mathrm{~m}^{3} \mathrm{~d}^{-1}$ per unit. The total energy needed to desalinate sea water can be as little as $5 \mathrm{kWh} \mathrm{m}^{-3}$ for a large state-of-the-art reverse osmosis desalination plant (Shannon et al., 2008). The fresh water produced is used in industry, agriculture and the home.

To estimate the costs of the carbon farming method proposed above, we consider a Jatropha curcas plantation of $10000 \mathrm{ha}$. It is assumed that the plantation is started on virgin desert land and cultivated over a period of $20 \mathrm{yr}$. For the climate simulations the locations of the plantation are arbitrarily chosen to be in Oman and Mexico. Based on data from the plantation in Luxor, Egypt, the annual water demand by Jatropha curcas planted at 940 plants ha $^{-1}$ is $880 \mathrm{~m}^{3} \mathrm{ha}^{-1} \mathrm{yr}^{-1}$. For a plantation of 10,000 ha practising placed irrigation, this would mean $24109 \mathrm{~m}^{3} \mathrm{~d}^{-1}$. The nominal capacity of a suitable desalination plant should therefore be around $25000 \mathrm{~m}^{3} \mathrm{~d}^{-1}$.

There are many and varied estimates of the cost of desalinated water. Yerimiyahu et al. (2007) gives a figure of 0.55 USD (0.42 EUR) per $\mathrm{m}^{3}$ of drinking water and
Methnani (2007) states that most estimates for the cost of water in "mega projects" are of the order of 0.5EUR per $\mathrm{m}^{3}$. Methnani's own calculations using the DEEP program of the International Atomic Energy Authority give values of $0.53-0.72 \mathrm{EUR} \mathrm{m}^{-3}$ and $0.85-1.28 \mathrm{EUR} \mathrm{m}^{-3}$ for RO and TD plants respectively when the energy source is a combined heat and power plant (CC) fuelled by fossil fuel. Corresponding figures when the energy source is an (atomic) high temperature gas reactor (HTGR) are $0.42-0.52 \mathrm{EUR} \mathrm{m}^{-3}$ for RO and 0.44-0.54EUR $\mathrm{m}^{-3}$ for TD. These figures show that the cost of producing desalinated water depends very much on the cost of the energy source and is particularly vulnerable to changes in the price of fossil fuel if a CC plant is used. One of the major advantages of the kind of carbon farming proposed here is that the project produces its own fuel after the third year in the form of tree trimmings and is thus relatively immune to the escalating price increases that will become inevitable as fossil fuels become rarer and more costly to extract. In our analysis, producing the fuel comes under the operational costs for the plantation so the cost of the desalinated water is mostly incurred for building, running and maintaining the machinery. This cost is therefore likely to be much closer to Methnani's HGRT estimates than those for $\mathrm{CC}$ and probably even lower since an atomic reactor is not required. We therefore use a global figure of $0.5 \mathrm{EUR} \mathrm{m}^{-3}$ in all subsequent calculations.

The carbon farming costs are estimated using the results from the Luxor plantation and other pilot Jatropha curcas plantations in India and Madagascar complemented by secondary data (Lal, 2004; Francis et al., 2005; Prueksakorn and Gheewawa, 2008). From these data, we compiled a comprehensive database disaggregated to the various farming activities (e.g., fertilization, irrigation, pruning, and harvesting), each specified in terms of labor, machinery and cash requirements as well as harvested products and carbon sequestered. We then submitted these input-output parameters to sensitivity testing and came up with the following average cost estimates for carbon farming: The costs include land lease (10 EUR ha $\left.{ }^{-1} \mathrm{yr}^{-1}\right)$, running the plantation including establishment and cultivation (200 EUR ha ${ }^{-1} \mathrm{yr}^{-1}$ ), erecting and running the irrigation system (100 EUR ha ${ }^{-1} \mathrm{yr}^{-1}$ ) and other running costs not connected with water $\left(310 \mathrm{EUR} \mathrm{ha}^{-1} \mathrm{yr}^{-1}\right)$. With an annual water demand of $880 \mathrm{~m}^{3} \mathrm{ha}^{-1} \mathrm{yr}^{-1}$, the total running costs would be $1060 \mathrm{EUR} \mathrm{ha}^{-1} \mathrm{yr}^{-1}$. In the coming $20 \mathrm{yr}$, 92$138 \mathrm{tC} \mathrm{ha}^{-1}$ can be sequestered equivalent to capturing 338$506 \mathrm{tCO}_{2} \mathrm{ha}^{-1}$ from the atmosphere. Thus, the total cost for carbon farming would be $42-63 \mathrm{EUR} \mathrm{t}^{-1} \mathrm{CO}_{2}$, which is similar to the cost estimates of conventional CCS technology which are around 54 EUR t ${ }^{-1} \mathrm{CO}_{2}$ (IPCC, 2005).

We estimate that it would take around $3 \mathrm{yr}$ before the plantation could provide enough spare biomass in the form of trimmings to produce the necessary heat to run the desalination plant (either directly in the case of TD or indirectly to run a generator for a RO plant). Until that time, the shortfall 
in energy would have to come from older, more mature plantations, from the electricity grid or from other sources. The biomass burned would release carbon as $\mathrm{CO}_{2}$, but this would be a small amount compared with the total carbon sequestered as biomass. Another obvious option would be the use of solar power plants.

\subsection{Impacts on regional climate}

\subsubsection{Feedback processes in desert regions}

Charney (1975) proposed self-stabilization effects in subtropical deserts related to feedback processes between surface albedo and precipitation. Prentice et al. (1992) extended this research by considering the feedback processes between vegetation and the hydrological cycle. By coupling a climate model to a dynamic vegetation model (Claussen, 1994) and application of conceptual models (Brovkin et al., 1998), two stable regimes were found in the Sahara: a desert equilibrium with low precipitation and absent vegetation and a green equilibrium with moderate precipitation and permanent vegetation cover. The impact of greening the planet on global temperature was studied by Kleidon et al. (2000). They demonstrated that greening the planet would result in a reduction of global mean surface temperature mainly due to enhanced surface evapotranspiration in combination with a modification of the global water cycle.

In the subtropical regions, which are under consideration in this work, a change of weather conditions can also be expected, as large-scale effects are produced by subsidence caused by the Hadley circulation while significant horizontal moisture transport is present at least in the summer season. In Oman, these effects are due to humid air advected from the south over the Arabian Sea whereas in Mexico, moist air is transported from the Gulf of Mexico to the Sonora desert. These events are a prerequisite for the induction of precipitation processes. However, the greening of the desert by a plantation with low levels of irrigation has more influence on the sensible heat flux and on changes of the atmospheric flow than on a change of evapotranspiration in the region of the plantation. Consequently, greening dry coastal areas has the potential to mitigate climate change, curb desertification, localize regional water cycles, and, consequently, promote rural development.

\subsubsection{Model set up}

To investigate whether the scenario mentioned above was likely to occur in large-scale Jatropha curcas plantations, we used a specially adapted land-surface-vegetationatmosphere model and applied it to two proposed pilot sites in Oman and Mexico. The study was executed with the Weather Research and Forecasting (WRF) model version 3.1 coupled to the NOAH ${ }^{1}$ land surface model (LSM) (Chen and Dudhia, 2001). In order to minimize systematic errors due to large-scale conditions, WRF-NOAH was driven by European Centre for medium-Range Weather Forecasts (ECMWF) analyses with a resolution of T799 (about $12.5 \mathrm{~km}$ grid resolution in the domains of interest). The nested domain was chosen to be a few tens of km larger than the planted region in the centre of the high-resolution domain. At the boundaries, one-way nesting was applied because we assumed that the scale of the planted region was still too small to induce large-scale feedback processes to the exterior domain.

As far as possible, the physics of WRF-NOAH was adapted to the physics of the ECMWF model for minimizing inconsistencies at the boundaries and the interior of the nested regions. The WRF physics included the short-wave and the long-wave radiation schemes of Dudhia (1989) and Mlawer et al. (1997), respectively, the Yonsei University boundary layer parameterization (Hong et al., 2006), and the two-moment cloud microphysics of Morrison et al. (2009). Deep and shallow convection were not parameterized.

To obtain simulations with optimal performance, WRF was operated with a convection permitting grid resolution of about $4 \mathrm{~km}$. This scale was chosen in order to simulate feedback processes between areas with different land-surface properties, atmospheric boundary layer (ABL), convection initiation, clouds and precipitation as realistically as possible. Recent results of convection-permitting simulations confirm their superior performance compared to models with convection parameterization with respect to the resolution of landsurface heterogeneity and orography (Schwitalla et al., 2008; Wulfmeyer et al., 2008, 2011; Rotach et al., 2009a, b) and to enhanced forecast skills (Schwitalla et al., 2011; Bauer et al., 2011). Convection-permitting resolution is essential in this study, particularly considering the relatively small spatial domain of the Jatropha curcas plantation. This was set to about $100 \mathrm{~km} \times 100 \mathrm{~km}$ oriented along the coast lines in both regions, Oman and Sonora (see Table 3).

A key accomplishment of this study was the optimization of an advanced land-surface model (LSM), in this case that of NOAH, in the regions of interest. This required an accurate description of sub-surface and surface soil properties and vegetation which we achieved by applying an advanced 20-category vegetation-land use data set (Friedl et al., 2002). Several improvements were implemented in the LSM in order to achieve the most realistic results. These included modification of the vegetation parameters to make them appropriate for Jatropha curcas and simulation of constant, regular irrigation. At the date of this study, a detailed parameter table

\footnotetext{
${ }^{1} \mathrm{NOAH}$ : joint land-surface model of $\mathrm{N}=$ National Center for Environmental Prediction (NCEP); $\mathrm{O}=$ Oregon State University (Dept of Atmospheric Sciences); A = Air Force; and $\mathrm{H}=$ Hydrologic Research Lab - NWS (National Weather Service) (now Office of Hydrologic Division).
} 
for Jatropha curcas was not available. However, as the vegetation properties of Jatropha curcas are close to Evergreen Broadleaf Forest (land use category 2), we started with this data set and optimized all parameters by a thorough study of recent published vegetation properties of Jatropha curcas (Gupta et al., 2002; Holl et al., 2007; Viña et al., 2004). The main differences from land use category 2 are the maximum leaf area index (3.2 instead of 6.48) and the minimum stomatal resistance $\left(130 \mathrm{~s} \mathrm{~m}^{-1}\right.$ instead of $\left.150 \mathrm{~s} \mathrm{~m}^{-1}\right)$. The main difference between the vegetation and desert is that the albedo is lower in the former from 0.38 to 0.12 , but the increase of the roughness length from $0.01 \mathrm{~m}$ to $0.5 \mathrm{~m}$ can also play a role in the development of convection in the target regions. This translates into different energy partitioning over the plantations. The remaining differences were not considered critical for this study, as these were expected to affect the resulting impact of the vegetation cover on atmospheric variables only at a secondary level.

Another special requirement was a reasonable estimate of the effect of irrigation. It turns out that irrigation has a negligible effect on the evapotranspiration, as long as the irrigation amounts derived in Sect. 3.2 are realistic. This is due to the fact that an irrigation of about $100 \mathrm{~mm} \mathrm{yr}^{-1}=0.27 \mathrm{~mm} \mathrm{day}^{-1}$, which is taken as reasonable approximation from Sect. 3.2 (Holl et al., 2007; Gebel and Yüce, 2008), translates into a rather low upper limit of transpiration during daytime: $0.27 \mathrm{~mm} \mathrm{day}^{-1}=0.27 \mathrm{~mm} /(12 \cdot 60 \cdot 60 \mathrm{~s}) \cong 16 \mathrm{~W} \mathrm{~m}^{-2}$. This result may be modified, if further data concerning vegetation dynamics and irrigation amounts become available. However, even if errors of around $100 \%$ are made, the partitioning of fluxes in the energy balance closure remains mainly driven by the sensible heat flux, which amounted to more than $500 \mathrm{~W} \mathrm{~m}^{-2}$ during daytime both in Oman and Sonora. Consequently, area averaged irrigation of the soil in the grid cell could be neglected and details of irrigation techniques did not have to be altered so that the soil moisture was kept the same as the initial values specified in the ECMWF driving data. Furthermore, the resulting low latent heat flux minimizes potential errors with respect to the assumptions made as to soil properties such as hydraulic conductivity. It is also worthwhile to point out that during our simulations the soil moisture remained very low but was still, with values of about 0.08 , higher than the wilting point of loam $(0.06)$ or sandy loam (0.047), which are the dominant soil types in the regions of interest. This demonstrates once again the consistency and reality of our results. Finally, care had to be taken to ensure the correct simulation of the vegetation in each grid cell of interest. A corresponding vegetation mask was developed and carefully tested in order to make sure that changes in land surface properties implemented in the model system exactly matched those in the regions selected in Oman and Sonora (Mexico).

Figure $4 \mathrm{a}$ and $\mathrm{b}$ present the locations of the plantations in Oman and the Sonora, respectively, as well as the successful

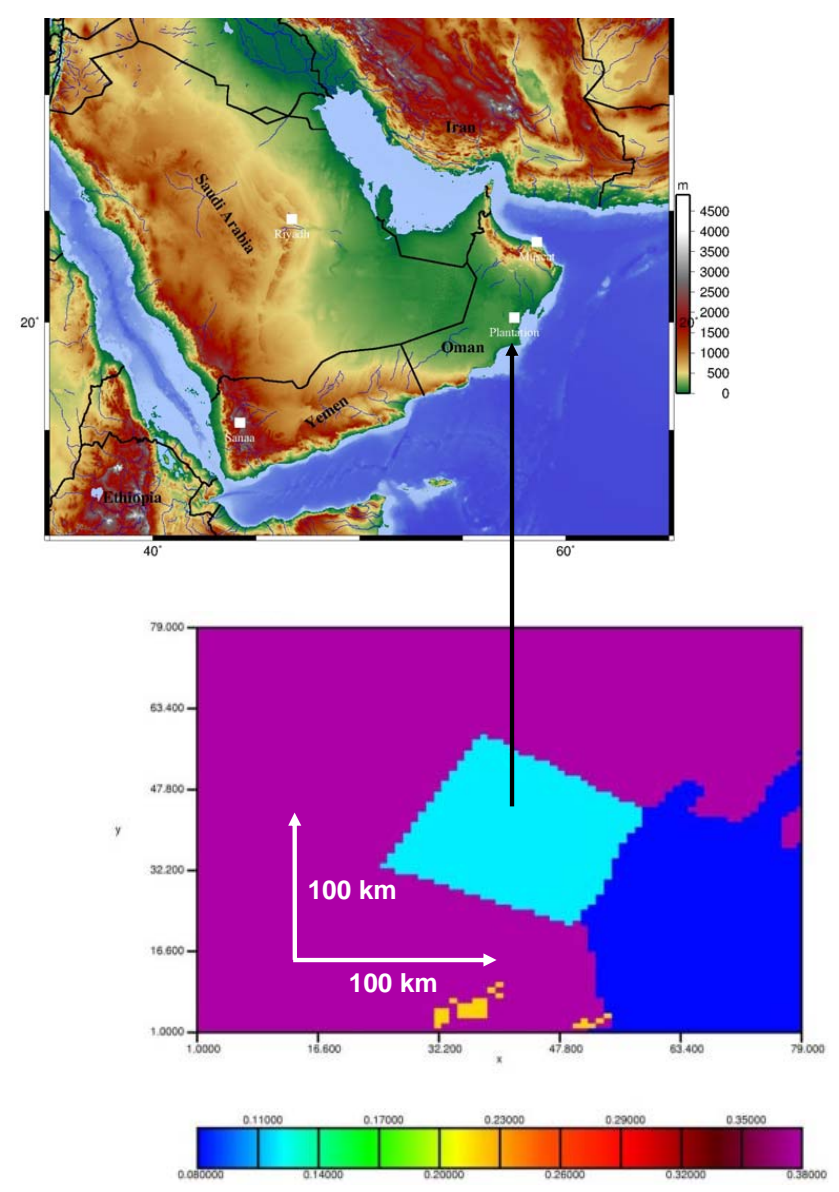

Fig. 4a. Upper panel: location of the plantation in Oman. Bottom panel: 2-D plots of the reduction in albedo caused by Jatropha curcas plantations in Oman.

implementations of the modified land use parameters in the LSM. The soil type in both Oman and Mexico was similar across the respective regions and the locations of the plantations at the coasts are easily detected due to changes in albedo.

\subsubsection{Results}

The model system was operated for a full year (2007) in order to detect feedback processes with high statistical confidence during all seasons. Four simulations were performed for the whole of 2007: Oman CONTROL (no changes of vegetation properties), Oman IMPACT (modification of land-surface properties by planting with Jatropha curcas in selected region), Sonora CONTROL, and Sonora IMPACT. The year 2007 was chosen, as typical weather prevailed and the most advanced and recent driving data could be used. For each simulation, seasonal averages and mean diurnal cycles with their corresponding standard deviations were determined for surface flux and atmospheric variables. The boundary layer 
Table 3. Configuration of the WRF model.

\begin{tabular}{lll}
\hline Properties & Oman & Mexico \\
\hline Model domain (horizontal) & $80 \times 80$ grid points & $75 \times 75$ grid points (rotated) \\
& $18.96^{\circ} \mathrm{N}, 55.88^{\circ} \mathrm{E}$ & $30.19^{\circ} \mathrm{N}, 114.89^{\circ} \mathrm{W}$ \\
& $-21.63^{\circ} \mathrm{N}, 58.72^{\circ} \mathrm{E}$ & $-32.73^{\circ} \mathrm{N}, 111.92^{\circ} \mathrm{W}$ \\
\hline Coordinates of Jatropha & $\mathrm{NE}: 20.45^{\circ} \mathrm{N}, 57.98^{\circ} \mathrm{E}$ & $\mathrm{NE}: 31.92^{\circ} \mathrm{N}, 112.97^{\circ} \mathrm{W}$ \\
curcas plantations & $\mathrm{SE}: 19.7^{\circ} \mathrm{N}, 57.65^{\circ} \mathrm{E}$ & $\mathrm{SE}: 31.33^{\circ} \mathrm{N}, 113.25^{\circ} \mathrm{W}$ \\
& $\mathrm{SW}: 20.05^{\circ} \mathrm{N}, 56.75^{\circ} \mathrm{E}$ & $\mathrm{SW}: 31.9^{\circ} \mathrm{N}, 114.7^{\circ} \mathrm{W}$ \\
& $\mathrm{NW}: 20.9^{\circ} \mathrm{N}, 57.22^{\circ} \mathrm{E}$ & $\mathrm{NW}: 32.37^{\circ} \mathrm{N}, 114.45^{\circ} \mathrm{W}$ \\
\hline Number of vertical layers & 45 & 45 \\
\hline Horizontal resolution & $4 \mathrm{~km}$ & $4 \mathrm{~km}$ \\
\hline Time step & $24 \mathrm{~s}$ & $24 \mathrm{~s}$ \\
\hline
\end{tabular}

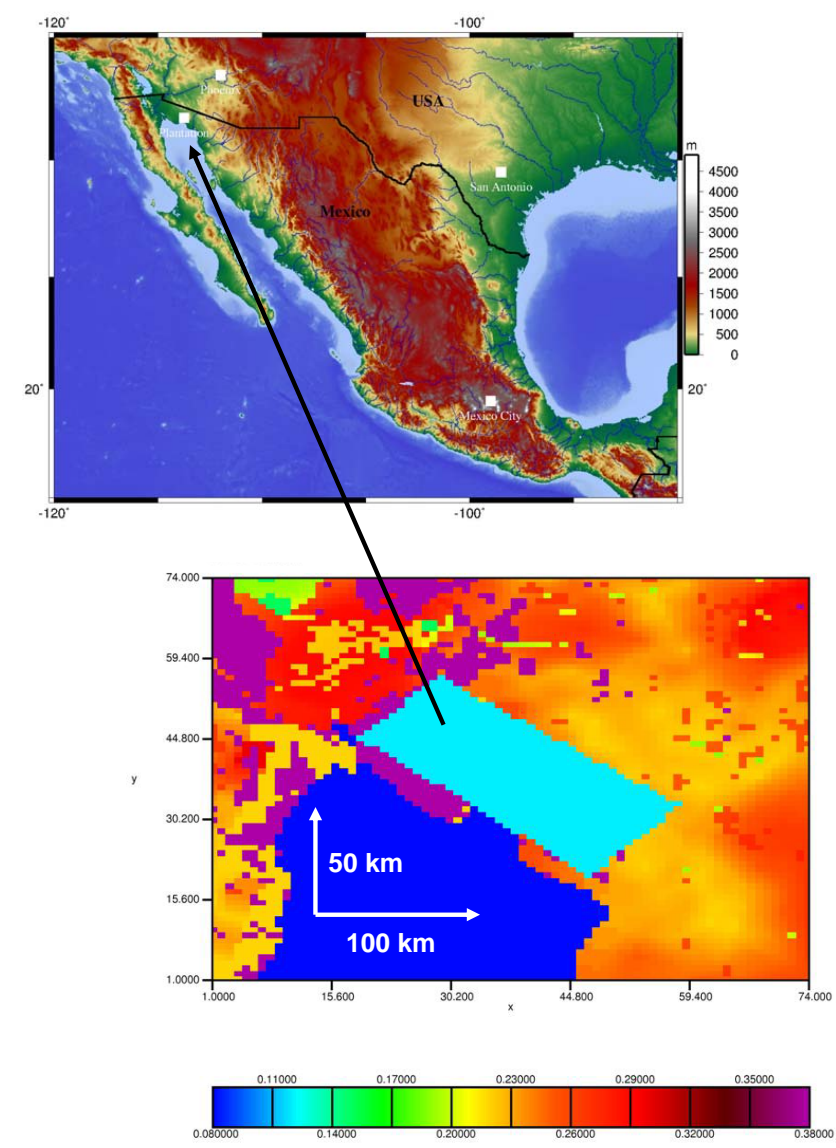

Fig. 4b. Upper panel: location of the plantation in the Sonora. Bottom panel: 2-D plots of the reduction in albedo caused by Jatropha curcas plantations in the Sonora.

depth, the cloud coverage, the rain rate, and the formation of dew were also analyzed.

The differences in albedo and transpiration between CONTROL and IMPACT lead to substantial changes in surface variables and atmospheric boundary layer (ABL) development. The diurnal cycles of the surface heat and the latent heat fluxes were substantially enhanced, particularly in summer. Whereas the latent heat flux was almost positive throughout the day, it became negative during night-time in spring, fall, and winter. This effect led to the formation of dew. For instance, in Oman, the formation of dew amounted to $46 \mathrm{~g} \mathrm{~m}^{-2}$ per night. Dew can be used by plants thus reducing the amount of water that has to be provided by irrigation. The exact amount, however, will be subject of future experiments and investigations.

The mean average surface temperatures over the Jatropha curcas plantations in both Oman and Mexico fell by more than $1{ }^{\circ} \mathrm{C}$ during all seasons. This effect was due to a nonlinear modification of the diurnal cycle of the sensible heat flux. We attribute the stronger cooling during night-time to the high emissivity of the plants. The increase of surface temperature during daytime was overcompensated by a reduction of temperature during night-time resulting in a decrease in mean temperature.

Another substantial effect was an increase of the atmospheric boundary layer (ABL) depth, particularly during summer time. This is demonstrated in Fig. 5, which shows the spatially resolved difference between the IMPACT and CONTROL planetary boundary layer depth (PBLH) over Oman and the Sonora. The mean PBLH over the plantations rose by more than $250 \mathrm{~m}$. The modification of the ABL depends on the local upstream conditions (wind speed and wind shear), the land surface energy balance closure (EBC, which was quite similar over both plantations), the local vertical stability of the ABL, the strength of the capping inversion, and the subsidence in the free troposphere. These effects resulted in a growth of a thermal internal ABL over the plantation on the upwind side and wake effects downstream of the plantations. Interestingly, in the Sonora and Oman an increase and a decrease of the ABL were found downstream of the plantations, respectively. These complex and non-linear effects are currently the subject of further studies. The increase of the ABL depth due to the higher sensible heat flux over the 

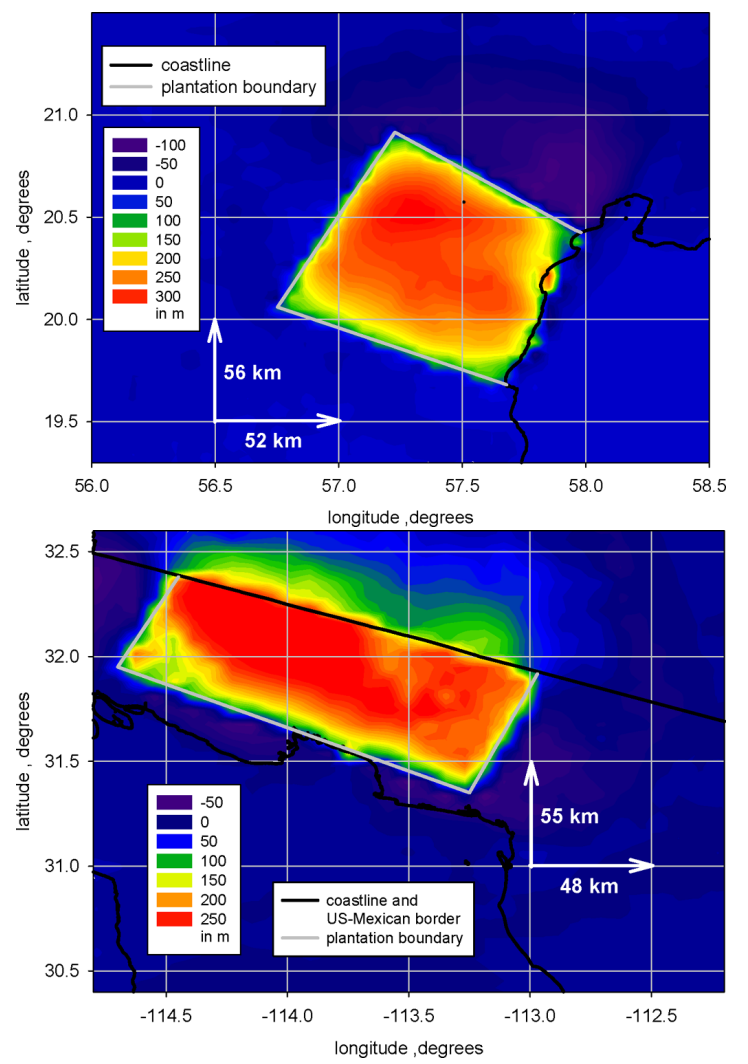

Fig. 5. Mean difference between IMPACT and CONTROL ABL top in summer over Oman (upper panel) and Sonora (bottom panel).

plantations caused a strong diurnal cycle. In the Sonora, at local noon, the ABL increased from $1800 \mathrm{~m}$ to $2580 \mathrm{~m}$ between CONTROL and IMPACT and, over Oman, the corresponding increases were $2000 \mathrm{~m}$ to $2750 \mathrm{~m}$, respectively. The mean ABL increased from $750 \mathrm{~m}$ to $976 \mathrm{~m}$ in Oman and from $685 \mathrm{~m}$ to $895 \mathrm{~m}$ in the Sonora. These increases mainly occurred during daytime.

Simultaneously, the increased latent heat flux caused more moisture to be mixed vertically in the ABL. In combination with the enhanced ABL depth, this led to an increased likelihood reaching the lifting condensation level in the ABL. Consequently, vertical stability was reduced increasing the probability of deep convection during summer time (June, July, August) both in Oman and Sonora.

Figure 6 shows the predicted changes in precipitation over $100 \mathrm{~km} \times 100 \mathrm{~km}$ Jatropha curcas plantations in both regions. Changes in rainfall were complex and tended to occur in streaks due to several events where convection was initiated. The increase in rainfall is substantial in summer and can amount to $160 \mathrm{~mm}$ along the streaks. This localization of the water cycle would be very beneficial for the biosphere in this region. Overall, precipitation increased on average by approximately $11 \mathrm{~mm}$ and $30 \mathrm{~mm}$ in Oman and the Sonora, respectively, and occurred mainly in summer.
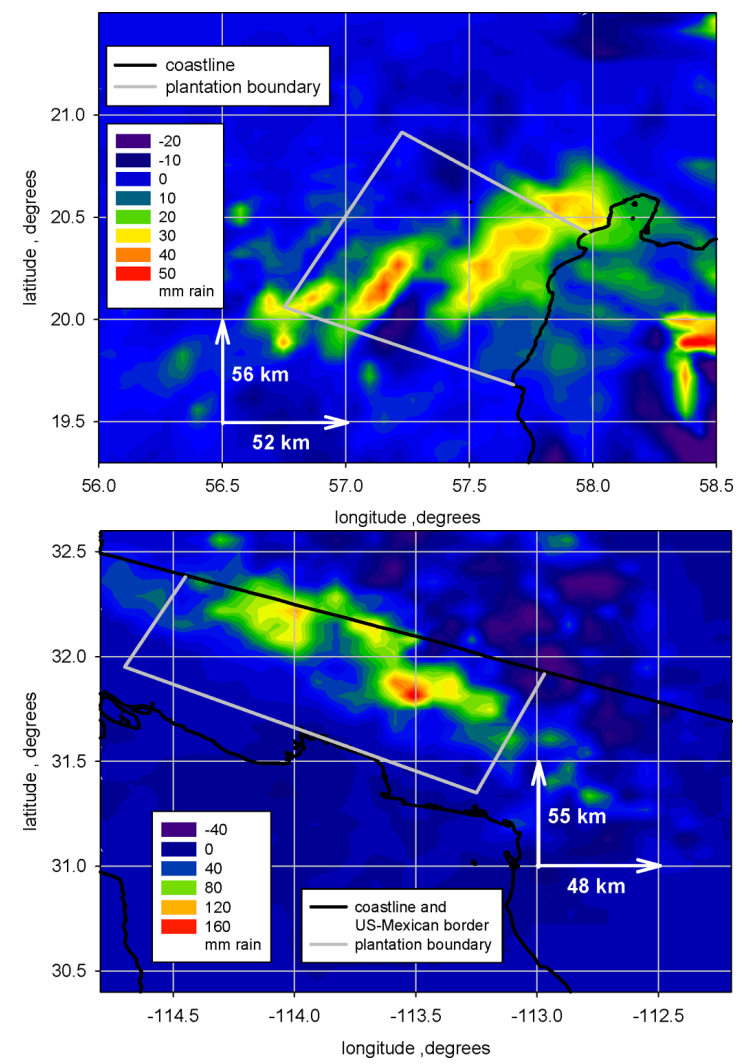

Fig. 6. Predicted differences in precipitation between planted and desert regions in Oman (upper panel) and Sonora (bottom panel) in summer 2007.

Compared with previous studies of land-surfacevegetation-atmosphere feedback processes with respect to precipitation (Charney, 1975; Claussen, 1994; Brovkin et al., 1998; Ornstein et al., 2009) our model had a much finer resolution. This gave a much deeper insight into the complex chain of processes leading to a positive precipitation feedback over the plantations and, more generally, to a greening of desert regions. The processes simulated in Oman and Sonora leading to precipitation are reliable and reasonable. To our knowledge, this study is the first to simulate the effect of the development of substantial plant cover in a tropical desert region with a specially adapted land-surface-vegetation-atmosphere model at such a fine resolution.

In the future, it is essential that this process chain is studied in more detail and related to the size, shape, and orientation of plantations as well as to the mean air flow. Particularly, it needs to be investigated whether, at a certain size of plantation, a point of self-stability can be reached where the precipitation enhancement is large enough for artificial irrigation to be no longer necessary. The GMC model of Ornstein et al. (2009) proposed increases in precipitation of up to $1400 \mathrm{~mm}$ per year for greening the Sahara. However, based on our research and experience with quantitative precipitation simulations, it is essential to confirm this with 
the new generation of convection-permitting models. In plantations of up to $100 \mathrm{~km} \times 100 \mathrm{~km}$, the predictions of our model are much more modest, so Jatropha curcas would always require water from desalination. It is for this reason that we have postulated the use of only those desert areas which are near the coast in order to minimize the costs of transporting water to the plants both vertically and horizontally. In any case, the precipitation increase of $11 \mathrm{~mm}$ and $30 \mathrm{~mm}$ in Oman and the Sonora, respectively, would spare some of the water needed for irrigation by the plantations in the summer season, which was estimated to be $25 \mathrm{~mm}$. It is important to quantify this in connection with the "self-stability" of the plantations. However, it should be noted that the precipitation increase is not the amount that ends up in the root zone for irrigation. This value depends on the runoff, the interception, the evapotranspiration, and the infiltration into the soil. The precipitation increase exhibits a diurnal cycle and, as it is driven by the increase of sensible heat flux, the accumulation of water in the soil depends on the diurnal cycle as well. Therefore, the increase in soil moisture and thus the reduction of water demand depends, in a non-linear manner, on the temporal and spatial evolution of the single, induced precipitation events. These analyses are beyond the scope of this work and subject of another publication, which is in preparation.

So far, in our simulations, effects on atmospheric variables downstream of the plantations were small. If larger scale plantations are simulated, the teleconnection of weather pattern also needs to be studied by increasing the domain simulated in the model around the plantations substantially or even by global simulations.

\section{Other expected impacts}

The oil in Jatropha curcas nuts is a viable and valuable source of biofuel (Devappa et al., 2010). Harvesting the nuts would reduce the amount of carbon sequestered by the plantation as a whole by about a third but in some situations this would be worthwhile in order to provide local employment and as an additional source of income for the plantation owners.

In some situations, one of the sources of "income" would be the increase in value of the land on which the Jatropha curcas was grown. The provision of a source of water and roads and the growth of vegetation would turn some desert coastal areas into desirable locations for the establishment of towns and villages.

On any proposed site, current land use rights and systems must be carefully checked and respected. Land may be used for occasional grazing, collection of desert fruits and flowers, extraction of minerals and other natural resources, hunting, tourism, cultural and religious uses, military training, etc.

Regarding desalination plants, environmental impacts will have to be considered at each specific location. Issues include the topography of the site, off-shore bathymetry, geology/seismology, and environmental concerns especially where brine from the desalination process is returned to the sea. The irrigation by desalination plants and waste water may lead to soil salinization. The accumulation of salt in the soil and the sensitivity of the plants to salinization have to be monitored continually in order to investigate potential negative effects and to develop methods for minimizing the impact of soil salinization on plant growth and crop yield.

As mentioned previously, we expect soil carbon stocks to increase as plantations mature. Also, as forests and plantations mature, large amounts of carbon are also sequestered in the soil. Mueller-Landau (2009) states that in African tropical forests, the soil holds as much carbon as the trees. Ferric Acrisols in the semi-arid coastal savannah zone of Ghana which is part of the extensive savannah belt of West Africa were found to contain 16-53t of carbon ha ${ }^{-1}$ under different types of cultivation (Dowuona and Adjetey, 2010). These figures give an idea of the potential for soil carbon storage if one were to start irrigating desert soils from scratch. Although decomposition will tend to reduce soil carbon stocks on a timescale of decades to centuries (Bird et al., 1999), we assume that in a hot, dry desert climate an appreciable portion will not be returned to the atmosphere (Lewis et al., 2009). Therefore, carbon storage as woody organic matter may not be a permanent solution but at least it would provide a breathing space during which longer term methods of storage and reduction of $\mathrm{CO}_{2}$ emissions could be found.

The ultimate fate of the plantations proposed in this paper can only be studied by further extensive experiments. It is probable that the trees on many of them would continue to grow, albeit at an ever decreasing rate, until it was no longer worthwhile irrigating them. At this stage, they could either be harvested or irrigation could be ceased. Harvested material could be stored or used as fuel. Using the material as fuel will, of course, release $\mathrm{CO}_{2}$ back into the atmosphere so, even if the cleared areas are replanted, the potential for net removal of atmospheric $\mathrm{CO}_{2}$ will be limited to that achievable in the first $20 \mathrm{yr}$ of growth, plus any carbon accumulated in the soil.

The option of storing the material could be achieved most easily by simply ceasing irrigation since the sites proposed for the plantations are hot dry deserts. This would be the only option in sites where the salinity of the soil had accumulated enough after $20 \mathrm{yr}$ to inhibit optimal growth. Incidentally, this will almost certainly be the case in our test site in Luxor where the irrigation water derived from sewage is relatively saline and may also contain other undesirable mineral compounds. Once again the amount of carbon sequestered is limited to that accumulated during $20 \mathrm{yr}$.

The most optimistic scenario would be one in which the plantations caused sufficient increase in precipitation, as predicted by our climate model, to maintain vegetative growth and establish permanent woodland or forest without artificial irrigation. 


\section{Conclusions}

We have introduced a transdisciplinary project for simulating the technological, economic and climatological impacts of carbon farming by Jatropha curcas plantations in dry coastal areas as well as their usefulness with respect to the Clean Development Mechanism (CDM). We have determined both by estimations and by field measurements that plantations of Jatropha curcas if established in hot, dry coastal areas around the world - should be capable of capturing 17-25t of carbon dioxide per hectare per year from the atmosphere (averaged over $20 \mathrm{yr}$ ). We found that a project to implement these ideas is technically feasible using recent advances in desalination methods such as reverse osmosis. Economically, carbon farming is competitive with carbon capture and storage (CCS). The total cost for carbon farming were estimated to be 42-63 EUR t ${ }^{-1} \mathrm{CO}_{2}$, which is similar to that of CCS technology (54 EUR t ${ }^{-1} \mathrm{CO}_{2}$; IPCC, 2005). In extensive sensitivity tests, we simulated the carbon sequestration cost in response to changes in market prices, labor requirements and biomass production (factor-by-factor approach). The most sensitive economic factors in our tests were the price of possible carbon credits and, not surprisingly, the underlying biomass growth curve. In the worst-case scenario, assuming no tree growth after year 12 and all economic factors to take on their most unfavourable values, sequestration costs would about double. In the best-case scenario, in contrast, sequestration costs could decrease by half. Climatologically, using a plantation size of $100 \mathrm{~km} \times 100 \mathrm{~km}$, for simulations with an advanced land-surface-vegetation-atmosphere model, we found a decrease of annual mean temperature over the plantations of the order of $1^{\circ} \mathrm{K}$ and an occurrence and/or enhancement of precipitation by approximately $11 \mathrm{~mm}$ and $30 \mathrm{~mm}$ averaged over the plantations during summer time in Oman and the Sonora, respectively. Particularly in Oman, formation of dew was predicted during spring, fall, and winter. Although this paper concentrates on the growth of $J a$ tropha in hot, dry areas, the models devised for the agronomic, economic and climatic aspects of this study are sufficiently flexible and transparent that calculations could be made for alternative scenarios provided relevant data were available.

Our ex ante assessment had to be based on many data sources and on simulation methods of different degrees of reliability. Particularly lacking were, information on the soil nutrients and water dynamics of Jatropha curcas, long-term (up to $20 \mathrm{yr}$ ) comprehensive data on its growth and data that could lead to a complete life cycle analysis. We would therefore strongly recommend establishing a pilot project using sea-water desalination in order to gather more precise onfield data. This would help us to optimize irrigation, cultivation and carbon monitoring and improve the assessment of possible environmental risks. Reflecting on the urgent need to take action on climate change we strongly recommend including carbon farming in dry coastal areas in the portfolio of mitigation strategies. Overall, we hope that we have demonstrated that carbon farming is a promising mitigation strategy deserving at least as much attention as many of the other geoengineering options, which are currently being discussed. The interdisciplinary combination of simulations presented in this work can be considered as a starting point for studying the sustainability of carbon farming.

Acknowledgements. We thank Peter Lawrence and Sabine Nugent of the Institute for Animal Production in the Tropics and Subtropics, University of Hohenheim, for their careful evaluation and for several major revisions of this manuscript. Furthermore, we thank Kirsten Warrach-Sagi, Hans-Stefan Bauer, Thomas Schwitalla, and Oliver Branch of the Institute of Physics and Meteorology, University of Hohenheim, for their contributions to the set up and the simulations of the WRF-NOAH model system. Furthermore, this research was supported by the DFG Research Unit 1695 on Regional Climate Change and the Water - Earth System Science Competence Center of the Universities of Hohenheim, Tübingen, and Stuttgart as well as the Helmholtz Centre for Environmental Research in Leipzig, Germany.

Edited by: A. Kleidon

\section{References}

Achten, W. M. J., Mathijs, E., Verchot, L., Singh, V. P., Aerts, R., and Muys, B.: Jatropha curcas biodiesel fueling sustainability?, Biofuel. Bioprod. Bior., 1, 283-291, doi:10.1002/bbb.39, 2007.

Angelini Luciana, G. A., Ceccarini, L., Nassi o Di Nasso, N., and Bonari, E.: Comparison of Arundo donax L. and Miscanthus x giganteus in a long-term field experiment in Central Italy: Analysis of productive characteristics and energy balance, Biomass Bioenerg., 33, 635-643, 2009.

Bauer, H.-S., Weusthoff, T., Dorninger, M., Wulfmeyer, V., Schwitalla, T., Gorgas, T., Arpagaus, M., and Warrach-Sagi, K.: Predictive skill of a subset of the D-PHASE multi-model ensemble in the COPS region, Q. J. Roy. Meteorol. Soc., 137, 287-305, doi:10.1002/qj.715, 2011.

Betts, R.: Implications of land ecosystem-atmosphere interactions for strategies for climate change adaptation and mitigation, Tellus B, 59, 602-615, 2007.

Bird, M. I., Moyo, C., Veenendaal, E. M., Lloyd, J., and Frost, P.: Stability of elemental carbon in a savanna soil, Global Biogeochem. Cy., 13, 923-932, 1999.

Boyd, P.W.: Ranking geo-engineering schemes, Nat. Geosci., 1, 722-724, 2008.

Brovkin, V., Claussen, M., Petoukhov, V., and Ganopolski, A.: On the stability of the atmosphere - vegetation system in Sahara/Sahel region, J. Geophys. Res., D24, 31613-31624, 1998.

Charney, J. G.: Dynamics of deserts and drought in the Sahel, Q. J. Roy. Meteorol. Soc., 101, 193-202, 1975.

Chen, F. and Dudhia, J.: Coupling an Advanced Land SurfaceHydrology Model with the Penn State-NCAR MM5 Modeling System. Part I: Model Implementation and Sensitivity, Mon. Weather Rev., 129, 569-585, 2001.

Claussen, M.: On coupling global biome models with climate models, Clim. Res., 4, 203-221, 1994. 
Costanza, R., D’Arge, R., De Groot, R., Farber, S., Grasso, M., Hannon, B., Limburg, K., and Van Den Belt, M.: The value of the world's ecosystem services and natural capital, Nature, 387, 253-260, 1997.

Devappa, R. K., Maes, J., Makkar, H. P. S., De Greyt, W., and Becker, K.: Quality of biodiesel prepared from phorbol ester extracted Jatropha curcas curcas oil, J. Am. Oil Chem. Soc., 87, 697-704, doi:10.1007/s11746-010-1547-4, 2010.

Doughty, C. E., Field, C. B., and McMillan, A. M. S.: Can crop albedo be increased through the modification of leaf trichomes, and could this cool regional climate?, Climatic Change, 104, 379-387, doi:10.1007/s10584-010-9936-0, 2010.

Dowuona, G. N. N. and Adjetey, E. T.: Assessment of carbon storage in some savanna soils under different landuse systems in Ghana, 2nd International Conference: Climate, Sustainability and Development in Semi-arid Regions, Ceara, Brazil, 1620 August 2010, available at: www.icid18.org/files/articles/1012/ 1281042320.pdf (last access: 2 October 2012), 2010.

Dudhia, J.: Numerical study of convection observed during the winter monsoon experiment using a mesoscale two-dimensional model, J. Atmos. Sci., 46, 3077-3107, 1989.

Fairless, D.: Biofuel: The little shrub that could - maybe, Nature, 449, 652-655, 2007.

Firdaus, M. S., Hanif, A. H. M., Safiee, A. S., and Ismail, M. R.: Carbon sequestration potential in soil and biomass of Jatropha curcas, Presented at: 19th World Congress of Soil Science, Soil Solutions for a Changing World, 1-6 August, Brisbane, 2010.

Friedl, M. A., McIver, D. K., Hodges, J. C. F., Zhang, X. Y., Muchoney, D., Strahler, A. H., Woodcock, C. E., and Schaaf, C.: Global land cover mapping from MODIS: algorithms and early results, Remote Sens. Environ., 83, 287-302, 2002.

Francis, G., Edinger, R., and Becker, K.: A concept for simultaneous wasteland reclamation, fuel production, and socio-economic development in degraded areas in India: Need, potential and perspectives of Jatropha plantations, Nat. Resour. Forum, 29, 12-24, 2005.

Gebel, J. and Yüce, S.: An Engineer's Guide to Desalination, VGB PowerTech Service GmbH, Essen, Germany, ISBN-13 978-386875-000-3, 2008.

Gupta, R. K., Prasad, T. S., and Vijayan, D.: Estimation of roughness length and sensible heat flux from WiFS and NOAA AVHRR data, Adv. Space Res., 29, 33-38, 2002.

Hellings, B. F., Romijn, H. A., and Franken, Y. J.: Working Paper: Carbon storage in Jatropha curcas trees in Northern Tanzania Published by the FACT foundation, available at: www. fact-foundation.com (last access: 28 July 2013), 2012.

Hohenegger, C., Brockhaus, P., Bretherton, C. S., and Schär, C.: The soil moisture-precipitation feedback in simulations with explicit and parameterized convection, J. Climate, 22, 5003-5020, 2009.

Holl, M. A., Gush, M. B., Hallowes, J., and Versfeld, D.: Jatropha curcas curcas in South Africa: An assessment of its Water Use and Bio-Physical Potential, Report to the Water Research Commission on the project "Investigation into the Impacts of LargeScale Planting of Jatropha curcas curcas on Water Resources through Process-Based Research and Modelling", WRC Report No. 1497/1/07, Water Resources Commission, South Africa, 2007.

Hong, S.-Y., Noh, Y., and Dudhia, J.: A new vertical diffusion package with an explicit treatment of entrainment processes, Mon.
Weather Rev., 134, 2318-2341, 2006.

Hussein, H. F., Saber, M. S. M., Radwan, S. M. A., and Abu-Seda, M.: Use Of Treated Domestic Sewage Effluent, International Conference on Water Resources \& Arid Environment, King Saud University, Riyadh, Kingdom of Saudi Arabia, 5-8 December 2004.

Intergovernmental Panel on Climate Change (IPCC): IPCC Special Report on Carbon Dioxide Capture and Storage, prepared by: Working Group III of the Intergovernmental Panel on Climate Change, edited by: Metz, B., Davidson, O. H., de Coninck, H. C., Loos, M., and Meyer, L. A., Cambridge University Press, Cambridge, United Kingdom and New York, NY, USA, 442 pp., available at: http://www.ipcc-wg3.de/publications/special-reports/ special-report-on-carbon-dioxide-capture-and-storage (last access: 28 July 2013), 2005.

IPCC: Contribution of Working Groups I, II and III to the Fourth Assessment Report of the Intergovernmental Panel on Climate Change, Core Writing Team, edited by: Pachauri, R. K. and Reisinger, A., IPCC, Geneva, Switzerland, 104 pp., 2007.

Kleidon, A., Fraedrich, K., and Heimann, M.: A green planet versus a desert world: Estimating the maximum effect of vegetation on the land surface climate, Climatic Change, 44, 471-493, 2000.

Kumar, S., Chaube, A., and Jain, S. K.: Post Copenhagen Summit Scenario: Attainment of substainable energy regime in India by Jatropha biodiesel, Energ. Environ., 22, 877-890, doi:10.1260/0958-305X.22.7.877, 2011.

Lal, R.: Carbon emission from farm operations, Environ. Int., 30, 981-990, 2004.

Lenton, T. M. and Vaughan, N. E.: The radiative forcing potential of different climate geoengineering options, Atmos. Chem. Phys., 9, 5539-5561, doi:10.5194/acp-9-5539-2009, 2009.

Le Quéré, C., Raupach, M. R., Canadell, J. G., Marland, G., Bopp, L., Ciais, P., Conway, T. J., and Woodward, F. I.: Trends in the sources and sinks of carbon dioxide, Nat. Geosci., 2, 831-836, 2009.

Lewis, S. L., Lopez-Gonzalez, G., Sonké, B., Affum-Bafoe, K., Baker, T. R., Ojo, L. O., Phillips, O. L., and Wöll, H.: Increasing carbon storage in intact African tropical forests, Nature, 457, 1003-1006, 2009.

Makkar, H. P. S., Becker, K., and Schmook, B.: Edible provenances of curcas from Quintana Roo state of Mexico and effect of roasting on antinutrient and toxic factors in seeds, Plant Food. Hum. Nutr., 52, 31-36, 1998.

Makkar, H. P. S., Kumar, V., Oyeleye, O. O., Angulo-Escalante, M. A., and Becker, K.: Traditional wisdom confirmed by scientific research: Jatropha curcas species from Mexico is non-toxic, Nature precedings, 22 January 2010, 1-4, hdl:10101/npre.2010.4155.1, 2010.

Methnani, M.: Influence of fuel costs on seawater desalination options, Desalination, 205, 332-339, 2007.

Metz, B., Davidson, O. R., Bosch, P. R., Dave, R., and Meyer, L. A.: Contribution of Working Group III to the Fourth Assessment Report of the Intergovernmental Panel on Climate Change, Cambridge University Press, Cambridge, United Kingdom and New York, NY, USA, 2007.

Mlawer, E. J., Taubman, S. J., Brown, P. D., Iacono, M. J., and Clough, S. A.: Radiative transfer for inhomogeneous atmospheres: RRTM, a validated correlated-k model for the longwave, J. Geophys. Res., 102D, 16663-16682, 1997. 
Morrison, H., Thompson, G., and Tatarskii, V.: Impact of cloud microphysics on the development of trailing stratiform precipitation in a simulated squall line: Comparison of one- and two-moment schemes, Mon. Weather Rev., 137, 991-1007, 1009.

Mueller-Landau, H.: Carbon cycle: Sink in the African jungle, Nature, 457, 969-970, 2009.

Ornstein, L., Aleinov, I., and Rind, D.: Irrigated afforestation of the Sahara and Australian Outback to end global warming, Climatic Change, 97, 409-437, doi:10.1007/S10584-009-9626-y, 2009.

Popluechai, S., Breviario, D., Mulpuri, S., Makkar, H. P. S., Mannish, R., Reddy, A. R., Palchetti, E., Gatehouse, A. M. R., Syers, K. J., O'Donnell, A. G. O., and Kohli, A.: Narrow genetic and apparent phenetic diversity in Jatropha curcas curcas: Initial success with generating low phorbol ester interspecific hybrids, Nature Precedings, 13 January 2009, 1-44, hdl:10101/npre.2009.2782.1, 2009.

Prentice, I. C., Cramer, W., Harrison, S. P., Leemans, R., Monserud, R. A., and Solomon, A. M.: A global biome model based on plant physiology and dominance, soil properties and climate, J. Biogeogr., 19, 117-134, 1992.

Prueksakorn, K. and Gheewala, S. H.: Full Chain Energy Analysis of Biodiesel from Jatropha curcas L in Thailand, Environ. Sci. Technol., 42, 3388-3393, 2008.

Rajaona, A. M., Brueck, H., Seckinger, C., and Asch, F.: Effect of salinity on canopy water conductance of young and 3-year old Jatropha curcas L., J. Arid Environ., 87, 35-41, 2012.

Ridgwell, A., Singarayer, J. S., Hetherington, A. M., and Valdes, P.: Tackling regional climate change by leaf albedo biogeoengineering, Curr. Biol., 19, 146-150, 2009.

Righelato, R. and Spracklen, D.: Carbon Mitigation by biofuels or by saving and restoring forests?, Science, 317, 5840, doi:10.1126/science.1141361, 2007.

Rotach, M. W., Ambrosetti, P., Ament, F., Appenzeller, C., Arpagaus, M., Bauer, H.-S., Behrendt, A., Bouttier, F., Buzzi, A., Corazza, M., Davolio, S., Denhard, M., Dorninger, M., Fontannaz, L., Frick, J., Fundel, F., Germann, U., Gorgas, T., Hegg, C., Hering, A., Keil, C., Liniger, M. A., Marsigli, C., McTaggart-Cowan, R., Montani, A., Mylne, K., Ranzi, R., Richard, E., Rossa, A., Santos-Muñoz, D., Schär, C., Seity, S., Staudinger, M., Stoll, M., Volkert, H., Walser, A., Wang, Y., Werhahn, J., Wulfmeyer, V., and Zappa, M.: MAP DPHASE: Real-time Demonstration of Weather Forecast Quality in the Alpine Region, B. Am. Meteorol. Soc., 90, 1321-1336, doi:10.1175/2009BAMS2776.1, 2009a.

Rotach, M. W., Ambrosetti, P., Ament , F., Appenzeller, C., Arpagaus, M., Bauer, H.-S., Behrendt, A., Bouttier, F., Buzzi, A., Corazza, M., Davolio, S., Denhard, M., Dorninger, M., Fontannaz, L., Frick, J., Fundel, F., Germann, U., Gorgas, T., Hegg, C., Hering, A., Keil, C., Liniger, M. A., Marsigli, C., McTaggartCowan, R., Montani, A., Mylne, K., Ranzi, R., Richard, E., Rossa, A., Santos-Muñoz, D., Schär, C., Seity, S., Staudinger, M., Stoll, M., Volkert, H., Walser, A., Wang, Y., Werhahn, J., Wulfmeyer, V., and Zappa, M.: Supplement: Additional applications of the D-PHASE data sets, B. Am. Meteorol. Soc., 90, electronic supplement: 28-32, 2009b.

Sampaio, E. V. S. B. and Silva, G. C.: Biomass equations for Brazilian semiarid catinga plants, Acta Bot. Bras., 19, 935-943, 2005.
Schwitalla, T., Zängl, G., Bauer, H.-S., and Wulfmeyer, V.: Systematic errors of QPF in low-mountain regions, Meteorol. Z., 17, 903-919, 2008.

Schwitalla, T., Bauer, H.-S., Wulfmeyer, V., and Aoshima, F.: Highresolution simulation over Central Europe: Assimilation experiments with WRF 3DVAR during COPS IOP9c, Q. J. Roy. Meteorol. Soc., 137, 156-175, doi:10.1002/qj.721, 2011.

Shannon, M. A., Bohn, P. W., Elimelech, M., Georgiardis, J. G., Marïas, B. J., and Mayes, A. M.: Science and technology for water purification in the coming decades, Nature, 452, 301-310, 2008.

Silva, E. N., Ribeiro, R. V., Ferreira-Silva, S. L., Viégas, R. A., and Silveira, J. A. G.: Comparative effects of salinity and water stress on photosynthesis, water relations and growth of Jatropha curcas plants, J. Aird Environ., 74, 1130-1137, 2010.

Steen, M. and Reed, D.: Knowledge reference for national forest assessments - Modelling for estimation and growth, FAO (IUFRO), 2004.

Tal, M., Rosental, I., Abramowith, R., and Forti, M.: Salt tolerance in Simmondsia chinensis: Water balance and accumulation of chloride, sodium, and proline under low and high salinity, Ann. Bot., 43, 701-708, 1979.

Viña, A. H., Geoffrey, M., and Gitelson, A. A.: Satellite monitoring of vegetation dynamics: Sensitivity enhancement by the wide dynamic range vegetation index, Geophys. Res. Lett., 31, L04503, doi:10.1029/2003GL019034, 2004.

Wulfmeyer, V., Behrendt, A., Bauer, H.-S., Kottmeier, C., Corsmeier, U., Blyth, A., Craig, G., Schumann, U., Hagen, M., Crewell, S., Di Girolamo, P., Flamant, C., Miller, M., Montani, A., Mobbs, S., Richard, E., Rotach, M. W., Arpagaus, M., Russchenberg, H., Schlüssel, P., König, M., Gärtner, V., Steinacker, R., Dorninger, M., Turner, D. D., Weckwerth, T., Hense, A., and Simmer, C.: The Convective and Orographically-induced Precipitation Study: A Research and Development Project of the World Weather Research Program for improving quantitative precipitation forecasting in low-mountain regions, B. Am. Meteorol. Soc., 89, 1477-1486, doi:10.1175/2008BAMS2367.1, 2008.

Wulfmeyer, V., Behrendt, A., Kottmeier, C., Corsmeier, U., Barthlott, C., Craig, G., Hagen, M., Althausen, A., Aoshima, F., Arpagaus, A., Bauer, H.-S., Bennett, L., Blyth, A., Brandau, C., Champollion, C., Crewell, S., Dick, G., Di Girolamo, P., Dorninger, M., Dufournet, Y., Eigenmann, R., Engelmann, R., Flamant, C., Foken, T., Gorgas, T., Grzeschik, M., Handwerker, J., Hauck, C., Höller, H., Junkermann, W., Kalthoff, N., Kiemle, C., Klink, S., König, M., Krauss, L., Long, C. N., Madonna, F., Mobbs, S., Neininger, B., Pal, S., Peters, G., Pigeon, G., Richard, E., Rotach, M. W., Russchenberg, H., Schwitalla, T., Smith, V., Steinacker, R., Trentmann, J., Turner, D. D., van Baelen, J., Vogt, S., Volkert, H., Weckwerth, T., Wernli, H., Wieser, A., and Wirth, M.: The Convective and Orographically Induced Precipitation Study (COPS): The Scientific Strategy, the Field Phase, and First Highlights, Q. J. Roy. Meteorol. Soc., 137, 3 30, doi:10.1002/qj.752, 2011.

Yermiyahu, U., Tal, A., Ben-Gal, A., Bar-Tal, A., Tarchitsky, J., and Lahav, O.: Rethinking desalinated water quality and agriculture, Science, 318, 920-921, 2007. 